REVISTA DE DERECHO UNED, NÚM. 20, 2017

\title{
LA INTERRUPCIÓN DE LA PRESCRIPCIÓN DEL PROCEDIMIENTO SANCIONADOR TRIBUTARIO POR ACTUACIONES ADMINISTRATIVAS TENDENTES A LA IMPOSICIÓN DE LA SANCIÓN TRIBUTARIA
}

\author{
THE INTERRUPTION OF THE EXPIRATION TERM OF TAX \\ PENALTY PROCEDURE FOR ADMINISTRATIVE ACTIVITIES \\ TENDING TO TAX PENALTY IMPOSITION.
}

\section{IVÁN PÉREZ JORDÁ}

Funcionario de Administración Local con habilitación de carácter nacional. Doctor en Derecho Financiero y Tributario. Profesor Asociado de Derecho Administrativo en la Universidad de Valencia. Licenciado en

Ciencias Políticas. Doctorando en Filosofía y Letras en la UNED

Resumen: El presente artículo se analiza detenidamente el supuesto interruptivo de la prescripción durante el procedimiento sancionador tributario.

Abstract: This article analyses carefully the interruption of the prescription because of tax penalties procedure.

Palabras clave: Prescripción, interrupción, procedimiento sancionador tributario.

Key words: Expiration term, interruption, tax penalty procedure.

Sumario: I. Introducción. II. Estudio del supuesto interruptivo de la prescripción del procedimiento sancionador tributario por cualquier acción de la Administración tributaria, realizada con conocimiento formal del interesado, conducente a la imposición de la sanción tributaria. II.A) Cualquier acción del órgano autorizado de la 
Administración Tributaria legalmente competente. II.B) Realizada con conocimiento formal del interesado. II.C) Conducente a la imposición de la sanción tributaria. III. Conclusiones.

\section{INTRODUCCIÓN}

El artículo 189.3..$^{\circ}$ de la Ley 58/2003, de 17 de diciembre, General Tributaria (LGT) establece las causas que interrumpen ${ }^{1}$ el plazo de prescripción para imponer sanciones tributarias ${ }^{2}$ en el procedimiento para la determinación de la responsabilidad dimanante de la infracción tributaria.

Una nota característica de los supuestos interruptivos de la prescripción, la puso de relieve Falcón y Tella al exponer la irrelevancia de la voluntad de las partes en la interrupción de la prescripción al ser esta un exponente de la soberanía del legislador para su regulación. Lo único importante es el sentido objetivo, la finalidad a que por sí mismo tienda el acto de que se trate ${ }^{3}$.

En igual sentido, opinamos, con Pérez Royo, que «los actos de interrupción de la prescripción son actos típicos, cuyos efectos se desarrollan de modo objetivo, con independencia de la representación que de los mismos se hagan sus autores. La prescripción afecta al plazo para imponer sanciones, al ejercicio de la acción para exigir responsabilidades derivadas de la comisión de infracciones. No afecta al ejercicio de la acción para declarar la existencia de la infracción, al

\footnotetext{
${ }^{1}$ Pese a que entendamos que los más correcto y respetuoso desde la perspectiva de un procedimiento separado respecto del seguido para la comprobación sería que sólo tuviesen eficacia interruptiva de la prescripción de la infracción las actuaciones sancionadoras propiamente dichas... rigen las mismas causas de interrupción de la prescripción del derecho a exigir el cumplimiento de la sanción que las examinadas en relación a la prescripción del derecho a exigir el pago de las deudas tributarias liquidadas y autoliquidadas. Martínez LAGo, M. A. y García DE LA Mora, L.: Lecciones de Derecho Financiero y Tributario, Iustel, Madrid, 2009, pág. 530; BLASco Delgado, C.: La prescripción de las infracciones y las sanciones, Civitas, Madrid, 2003, págs. 151 a 170.

2 LAMOCA PÉREz estima que la regulación del instituto de la prescripción aplicado a la vigencia de la acción para imponer sanciones es fruto matizado de la regulación que de la prescripción se hace en los artículos 66 a 70 LGT. Fruto matizado y reducido a la mínima expresión, lo que no es precisamente la mejor de las soluciones en orden a evitar problemas, sobretodo de prueba. LAmoca Pérez, C.: Infracciones y sanciones tributarias. Análisis crítico del nuevo sistema de infracciones y sanciones en la Ley General Tributaria, CEF, Madrid, 2005, pág. 213.

3 FalCón y Tella, R.: La prescripción en materia tributaria, La Ley, Madrid,1992, pág. 148.
} 
procedimiento sancionador mediante el cual se pueda declarar que, determinados hechos, determinadas acciones u omisiones, son constitutivas de infracción para, a renglón seguido, apreciar de oficio la aplicación necesaria de la prescripción de la acción para imponer sanciones ${ }^{4} »$.

En relación con este precepto, es preciso señalar que las causas de interrupción a las que se refiere no pueden identificarse totalmente con las que recoge el artículo 1973 del Código Civil, con las que existe una gran similitud ${ }^{5}$, y que, lógicamente, deben adaptarse a las especialidades del derecho tributario y del derecho sancionador tributario. De nuevo, se pone de manifiesto la relevancia que el Derecho privado ha tenido en la LGT y las consecuencias que su influencia ha provocado, las cuales, también se han dejado sentir en la regulación de los supuestos de interrupción de la prescripción.

La ubicación del articulado se aleja ${ }^{6}$ de los preceptos que regulan la deuda tributaria y, en concreto, de los destinados a una de sus formas de extinción como es la prescripción (arts. 66 a 70 LGT) 7 . Esta

${ }^{4}$ La LGT no ha regulado expresamente la prescripción correspondiente a la declaración de infracciones, circunstancia esta que obligaría indefectiblemente a abrir el expediente sancionador siempre que hubiera acciones que pudieran ser constitutivas de infracción aunque fuese manifiesta la prescripción de la acción para imponer sanciones. Habría, pues, que iniciar el procedimiento sancionador, calificar los hechos y conductas y, dentro del propio procedimiento, apreciar la existencia de la prescripción, no cabría hacerlo fuera del procedimiento sancionador ni antes de calificar las conductas. La solución no es más que la expresión de la posición jurisprudencial al respecto, la cual exige que la prescripción se aprecie siempre dentro del procedimiento penal. En consecuencia, tiene que haber infracción y no la hay mientras no haya pronunciamiento administrativo en tal sentido, para que haya prescripción de las responsabilidades que se deriven de aquélla, para que se aprecie la prescripción de la acción para imponer sanciones. LAMOca PÉrEz, C.: Infracciones... op. cit. págs. 213 y 214.

${ }^{5}$ Cita FALCón: en el mismo se establece que «la prescripción de las acciones se interrumpe por su ejercicio ante los Tribunales por reclamación extrajudicial del acreedor y por cualquier acto de reconocimiento de la deuda por el deudor». FERREIRO LAPATZA, J. J.: "La extinción de la obligación tributaria», RDFHP, Civitas, núm. 77, 1968, pág. 1068; Basándose en el carácter ex lege de la infracción tributaria y el fundamento exclusivamente objetivo de la prescripción de la misma: FALCón Y TELLA, R. La prescripción ...op. cit. pág. 148.

${ }^{6}$ Así se reitera varias veces en la exposición de motivos «el título IV regula de modo autónomo la potestad sancionadora y el título $\mathrm{V}$ regula la revisión de actos administrativos en materia tributaria»(I), «El título IV regula, a diferencia de la Ley 230/1963, de 28 de diciembre, General Tributaria, la potestad sancionadora en materia tributaria de forma autónoma y separada de la deuda tributaria, tanto los aspectos materiales de tipificación de infracciones y sanciones como los procedimentales, estos últimos ausentes en dicha ley»(V).

${ }^{7}$ La regulación del instituto de la prescripción aplicado a la vigencia de la acción para imponer sanciones es fruto matizado de la regulación que de la prescripción se 
situación ha influido en el régimen prescriptivo de la responsabilidad derivada de la comisión de una infracción, y en los motivos de interrupción del mismo que legalmente se establecen, que deben ser interpretados a la luz de los principios que informan la potestad sancionadora ${ }^{8}$, ex art. $178.1 .^{\circ}$ LGT $^{9}$.

Atendida la separación de los procedimientos de liquidación y sancionador, iniciada en la Ley 1/1998, de 26 de febrero, de Derechos y Garantías de los Contribuyentes (LDGC), para algunos ${ }^{10}$, es coherente seguir admitiendo, y legalmente así se establece, que las actuaciones del procedimiento que afectan al primero interrumpen la prescripción de la infracción, eludiendo que el principio de independencia de procedimientos pudiera interpretarse aplicándolo hasta sus últimas consecuencias, de manera que sólo la iniciación del procedimiento sancionador pudiera de interrumpir el plazo de prescripción de la infracción. Por nuestra parte, seguimos defendiendo la aplicación estricta de la independencia de los procedimientos de aplicación de los tributos y el sancionador.

En cualquiera de los casos, para que la interrupción se produzca y sea eficaz se exige de su «realización con conocimiento formal ${ }^{11}$ del

hace en los artículos 66 a 70 LGT. Fruto matizado y reducido a la mínima expresión, lo que no es precisamente la mejor de las soluciones en orden a evitar problemas, sobretodo de prueba. LAMOca PÉREZ, C.: Infracciones... op.cit. págs. 212 y 213; Según el artículo 25.2. ${ }^{\circ}$ LGT «2. Las sanciones tributarias no tienen la consideración de obligaciones accesorias».

${ }^{8}$ El enunciado legal potestad sancionadora, se podría llamar con más propiedad, por ejemplo "subordinación sancionadora», en consideración a sus destinatarios. Aníbarro Pérez, S y Sesma Sánchez, B.: Infracciones y sanciones tributarias, Lex Nova, Valladolid,2005, pág. 10.

${ }^{9} \mathrm{El}$ Derecho penal común, en virtud del mandato expreso del art. 7.2 de la LGT, ha de aplicarse en los casos en que sea necesario como Derecho supletorio. En efecto, respecto de la materia regulada por los arts. 181 a 212 de la LGT, el Derecho común al que alude el art. 7.2 de la LGT no puede ser otro que el Derecho penal común contenido, fundamentalmente, en el Código penal. F. Ferreiro Lapatza, J. J.: Curso de Derecho Financiero Español: Instituciones, Marcial Pons, Madrid,2006, pág. 549.

${ }^{10}$ Críticamente se han posicionado algunos autores que manifiestan «no parece que ello se avenga bien con las exigencias a las que responde la separación de procedimientos, ni con el rigor que la jurisprudencia del Tribunal Supremo viene exigiendo para que una actuación administrativa se erija en causa de interrupción de los plazos de prescripción: sólo se reconoce eficacia interruptiva a aquellas actuaciones administrativas que efectivamente hagan avanzar el procedimiento de que se trate». MARtín Queralt, J.; Lozano Serrano, C.; Tejerizo lópez, J. y Casado Ollero, G.: Curso de Derecho Financiero y Tributario, Tecnos, Madrid,1996, pág. 531.

${ }^{11}$ Por conocimiento formal entiende la STSJ de la CA Valenciana de 18 de febrero de 1991 (RGD núm. 558) «no sólo el directo, sino también el indirecto o implícito a una posterior actuación del contribuyente que permita deducir o convalidar la ausencia de aquél, si bien la citada sentencia niega eficacia interruptiva a la notificación 
interesado u obligado ${ }^{12}$ », correspondiendo a la Administración la prueba de que la notificación se ha practicado ${ }^{13}$, siguiendo el régimen general de las notificaciones administrativas establecido en los artículos 39 a 46 de la Ley 39/2015, de 1 de octubre, de Procedimiento Administrativo Común de las Administraciones Públicas (LPACAP), con las especialidades establecidas en los artículos 109 a 113 de LGT y 114 a 115 del Real Decreto 1065/2007, de 27 de julio, por el que se aprueba el Reglamento General de las actuaciones y los procedimientos de gestión e inspección tributaria y de desarrollo de las normas comunes de los procedimientos de aplicación de los tributos $(\mathrm{RGGI})^{14}$, todo ello por la remisión del apartado $4 .^{\circ}$ del artículo 208 LGT a la sección 3. a del capítulo II del título III de la LGT.

A continuación procederemos al estudio del supuesto de interrupción que se recoge en el artículo $189.3 .^{\circ}$ a) LGT, tratando de interpretar el supuesto de interrupción de la prescripción de la infracción, a que se refiere el mencionado precepto, a la luz de los principios que informan la prescripción dentro de la potestad sancionadora del Estado.

efectuada al conserje del edificio donde habita el interesado, por no constar el conocimiento de este último»; cuestión distinta es el efecto derivado de la negativa del conserje a la firma de la diligencia de entrega, que no puede equivaler a notificación válida, al no efectuarse el rechazo por el interesado o su representante, como exige el art. 111.2 LGT. La ausencia de identificación del receptor, incluso la falta de firma de éste, si se convalida mediante diligencia de entrega suscrita por dos Agentes tributarios se considera válida su fuerza probatoria. (RTEAC de 3 de febrero de 1993 y STSJ de Cataluña de 21 de febrero de 2003). AA. VV.(Dir. Martínez La Fuente, A.): Estudios sobre la nueva Ley General Tributaria. Homenaje a D. Pedro Luís Serrera Contreras, MEH, IEF, Madrid,2004, pág. 399.

${ }^{12}$ Hubiera resultado más apropiado hablar de presunto infractor, sin embargo, el legislador no puede cesar de relacionar el procedimiento sancionador tributario con el de aplicación de los tributos. En este orden de cosas, advertimos que en el apartado a) y b) del párrafo $3 .^{\circ}$ del artículo 189 LGT, diferencia el sujeto infractor denominándole interesado en el primer caso, y obligado en el segundo supuesto, aunque en ambos casos se refiere al mismo tipo de sujeto infractor.

${ }^{13}$ Solchaga Loitegui, J.: Extinción de la deuda tributaria y procedimiento recaudatorio. Aportaciones recientes al tema. CT, núm. 27, 1973, pág. 136 citado por FALCóN Y TELLA, R. La prescripción... op.cit. pág. 128.

${ }^{14}$ El régimen general de notificaciones de la Ley 39/2015, de 1 de octubre, del Procedimiento Administrativo Común de las Administraciones Públicas (LPACAP), y la aplicación de las especialidades tributarias contenidas en los artículos 109 a 113 de la LGT, que se encuentran en el capítulo II del Título III de la LGT relativo a los procedimientos de aplicación de los tributos, se entiende de aplicación en el ámbito sancionador tributario no sólo por la remisión del artículo 178.1 de la LGT a los principios reguladores de la potestad sancionadora en materia administrativa, sino también por mor de la remisión prevista en el artículo 208.4. ${ }^{\circ}$ LGT. 


\section{ESTUDIO DEL SUPUESTO INTERRUPTIVO DE LA PRESCRIPCIÓN DEL PROCEDIMIENTO SANCIONADOR TRIBUTARIO POR CUALQUIER ACCIÓN DE LA ADMINISTRACIÓN TRIBUTARIA, REALIZADA CON CONOCIMIENTO FORMAL DEL INTERESADO ${ }^{15}$, CONDUCENTE $^{16}$ A LA IMPOSICIÓN ${ }^{17}$ DE LA SANCIÓN TRIBUTARIA}

\footnotetext{
${ }^{15}$ Por conocimiento formal hay que entender la recepción por el infractor de la notificación administrativa correspondiente que garantiza la comunicación de que se trate. Por otra parte, la acción administrativa tiene que estar dirigida a la efectiva determinación de la responsabilidad y no tener una función meramente interruptiva. CALVO ORTEGA, R.: Curso de Derecho Financiero. Derecho Tributario. Parte General, Civitas, Madrid, 2001, pág. 245; En relación a la normativa anterior, la LGT de 1963, muy similar a la actual, es curiosa en este ámbito la postura de la jurisprudencia, que se ha mostrado sorprendentemente estricta en los referente a la exigencia de los requisitos necesarios para la consideración de la notificación como válida, admitiendo únicamente aquélla que pueda asegurar un conocimiento íntegro por parte del interesado, así la SAN de 6 de abril de 1993. (1) Calvo Ortega lo considera como un tipo de sustitución. Calvo OrTEga, R.: Curso de Derecho... op. cit. pág. 173; Exigiendo el conocimiento fehaciente del sujeto infractor, considerando que la falta de notificación o la notificación defectuosa anula la eficacia interruptiva de la actuación administrativa, según criterio reiterado de la jurisprudencia y doctrina administrativa. BAYONA De Perogordo, J. J. y Soler Roch, M. T.: Materiales de Derecho Financiero, Compás, Alicante, 1999, pág. 310; de tal dicción se infiere la inoperatividad de aquellas actuaciones en que haya resultado infructuosa la notificación al presunto responsable. BuEYo DíEZ-JALÓN, M.: «Extinción y reducción de las sanciones tributarias: Los criterios de graduación de las sanciones Tributarias», en obra colectiva AA. VV (Dir. MARTínEZ LA FuENTE, A.): La Nueva Ley General Tributaria. IEF, 2004, pág. 845; Las actuaciones iniciadas cerca de la sociedad dominante, en su calidad de representante del grupo consolidad, interrumpe la prescripción de todas las sociedades englobadas en el mismo. Por el contrario, las actuaciones iniciadas cerca de una o varias sociedades dominadas, sin la presencia en su calidad de representante de la sociedad dominante, sólo surtirán efectos respecto de la sociedad o sociedades dominadas a las que allega la actuación, en modo alguno interrumpirá la prescripción de las obligaciones tributarias correspondientes al grupo, único sujeto pasivo del Impuesto de Sociedades. Querol García, M. T.: Régimen de infracciones y sanciones tributarias, Deusto, Bilbao, 1991, pág. 50; el art. 65.4 del TRLIS norma «Las actuaciones administrativas de comprobación o investigación realizadas frente a la sociedad dominante o frente a cualquier entidad del grupo fiscal, con el conocimiento formal de la sociedad dominante, interrumpirán el plazo de prescripción del Impuesto sobre Sociedades que afecta al citado grupo fiscal».

${ }^{16}$ Así la jurisprudencia ha venido a insistir en que, no cualquier acción debe ser susceptible de interrumpir la prescripción, ya que, como ha dicho el TS en reiteradas sentencias, no cualquier acto tiene eficacia interruptiva sino sólo los tendencialmente ordenados a iniciar o proseguir los respectivos procedimientos administrativos, o que, sin responder meramente a la finalidad de interrumpir la prescripción, contribuyan efectivamente a la liquidación, recaudación o imposición de sanción en el marco del impuesto controvertido, por todas la STS de 16 de abril de 2003. PÉREZ DE AYALA, J. L. y PéreZ De Ayala BecerRIL, M.: Fundamentos de Derecho Tributario, Edersa, Dijusa, Madrid, 2004, pág. 233; Se requiere que las actuaciones administrativas de las que se quiere obtener estos efectos vayan encaminadas directamente a iniciar un procedimiento, o bien si éste ya está en marcha que se haga avanzar el mismo. Debe rechazarse con toda contundencia el efecto interruptivo de aquellas actuaciones que no añadan nada a la situación jurídica objeto de eventual conocimiento. Los meros recordatorios o simplemente el poner en conocimiento una determinada situación no basta para producir la paralización del cómputo de los plazos, sino que debe estar orientada directamente a conseguir las finalidades que se persiguen en el procedimiento. AGUADO I CUDOLÀ, V.: Prescripción y caducidad en el ejercicio de potestades administrativas, Marcial Pons, Madrid,1999, pág. 40; BLASCo DelgaDo, C.: La prescripción... op. cit. págs.157 a 166.

${ }^{17}$ Dicha expresión no debe sino resultar sinónima de la expresión iniciación del procedimiento sancionador tributario mediante la notificación formal de acuerdo de iniciación, salvo
} 
El supuesto que nos atañe en el presente artículo exige el análisis de sus diversos elementos. En primer lugar, se requiere de una acción administrativa tributaria sancionadora, para seguidamente reclamar de su notificación formal al interesado o su representante, terminando el mandato con la necesidad que dicha actividad sea rectamente dirigida a la imposición de la concreta infracción tributaria cuyo procedimiento se trata de interrumpir y no de cualquier otra infracción.

No podemos dejar de expresar que en el presente artículo no se tratará la interrupción de la prescripción del procedimiento sancionador tributario por acciones administrativas regularizadoras, pues, pese a encontrarse íntimamente relacionados, excedería del objeto de este estudio, lo que rogamos nos disculpe amablemente el lector.

\section{II.A) Cualquier acción del órgano autorizado de la Administración Tributaria legalmente competente}

Con anterioridad se cuestionaba por la doctrina la virtualidad interruptiva de las actuaciones de comprobación e investigación, puesto que se entendía que, desde la separación de procedimientos introducida por la LDGC, no podía mantenerse este motivo de interrupción, ya que el procedimiento de liquidación ya no suponía la imposición de sanciones, y por tanto, no hacia avanzar el procedimiento sancionador ${ }^{18}$. Por ello, con la actual regulación, el legislador ha querido

el caso de renuncia a la tramitación separada en cuyo caso, la primera actuación se producirá con la notificación del inicio de dicha tramitación conjunta ex art. 27.1 RGRST y 208.2 LGT. GaRBERí LlOBREGAT, J.(Dir.); BuITRÓN RAMíreZ, G. et alii: Procedimiento Sancionador. Infracciones y Sanciones Tributarias. (Comentarios, Jurisprudencia, Formularios, Ejemplos Prácticos y Legislación). Tomo I, Tirant Lo Blanch, Valencia, 2005, págs.589 y 590.

${ }^{18}$ Carecen de virtualidad interruptiva las llamadas diligencias para interrumpir la prescripción -que se realizan para este único efectos- de las diligencias que tienen otra causa y finalidad para que, a la vez, interrumpen la prescripción. MANTERo SÁENZ, A.: «La prescripción en el Derecho tributario», HPE, núm. 52, 1973, pág. 167, citado por FALCón; Para que una actuación administrativa interrumpa la prescripción es necesario que tienda efectivamente al reconocimiento, liquidación o exigencia del crédito tributario, o a la imposición de la sanción que corresponda, y en este sentido ha de tratarse de actuaciones qué hagan avanzar el procedimiento de gestión o el procedimiento sancionador. Carecen de virtualidad interruptiva, en consecuencia, las llamadas diligencias para interrumpir la prescripción, es decir, las notificaciones que únicamente pretenden alcanzar dicha eficacia Interruptiva, o que, por cualquier otra razón no hacen avanzar el procedimiento FALCón y TELLA, R.: Análisis crítico de jurisprudencia en materia de prescripción de las infracciones y sanciones tributarias, IEF, Madrid, núm. 76, 1990, pág. 84. EsCRIBANO LóPEZ, F.: «El procedimiento sancionador tributario en la Ley de Derechos y Garantías de los Contribuyentes y su desarrollo reglamentario», $R C T-E F$, núm. 196, 1999, págs. 18 y ss. Concluye este autor que «la prescripción de la acción para sancionar es independiente de la prescripción de la 
dejar claro que las actuaciones citadas, además de otras, interrumpen el plazo de prescripción de la infracción, y por si acaso existían dudas, también por la iniciación del procedimiento sancionador, dudas que con el artículo 30 Ley 40/2015, de 1 de octubre, de Régimen Jurídico del Sector Público (LRJSP), deben quedar disipadas ${ }^{19}$.

$\mathrm{Al}$ respecto, es necesario recordar que de la interpretación que se ha realizado de la regulación de la prescripción en estos ámbitos, se desprende que el único motivo que debería interrumpir la prescripción en el ámbito tributario es la iniciación del procedimiento sancionador contra el presunto infractor ${ }^{20}$. Este debería ser el techo máximo al que puede aspirar el legislador tributario a la hora de determinar los supuestos de interrupción de la prescripción de las infracciones, ahora bien, ello no obsta para que puedan existir algunas especialidades derivadas de las particularidades del procedimiento sancionador en el ámbito tributario ${ }^{21}$.

acción para determinar la deuda tributaria*y, en consecuencia, «los actos tendentes a la concreción de la deuda tributarte no son actos interruptivos de la prescripción de la acción para sancionar. La autonomización de ambos procedimientos exige,..., que los plazos sean, asimismo, autónomos. Funciones diversas, procedimientos separados, plazos autónomos». PÉREZ ROYO, F.: Derecho Financiero y Tributario. Parte General, Madrid, Edit. Civitas, 8. ${ }^{\text {a }}$ ed., 1998, pág. 323, mantiene que «A pesar de la letra de la LGT no es posible entender que la acción para imponer sanciones se interrumpe, como la de la acción para liquidar, por cualquier acto de la Administración, sino solamente por el acto de notificación de apertura del procedimiento sancionador». En el mismo sentido, De Miguel Canuto, E.: La prescripción de las infracciones y sanciones tributarias, Tirant lo Blanch, Valencia,2000, págs. 24 y ss; resulta incongruente con la pretendida separación rotunda entre procedimiento inspector o procedimiento sancionador, ya que responde todavía a la situación anterior en que mediante la incoación del acta se realizaba la liquidación de la cuota, los intereses, los recargos y las sanciones que, en su caso, pudieran proceder. RICARDO HoYOS, J.:«El procedimiento sancionador tributario como procedimiento separado», $Q F$, núm. 3, 2001.

${ }^{19}$ Debe advertirse que no basta con que se produzca el acto en cuestión, sino su notificación correcta al interesado antes de la prescripción para que produzca el efecto interruptivo; así como que no basta cualquier actuación hecha meramente con este fin, sino que ha de responder al efectivo ejercicio de las potestades, rechazando la jurisprudencia las diligencias para interrumpir la prescripción que no suponen un avance en los respectivos procedimientos. MARTín QUERALT, J. et alii: Derecho Tributario... op. cit. pág. 206; Blasco Delgado, C.: La prescripción ...., op. cit pág. 159.

${ }^{20}$ Lozano Cutanda consideraba, en relación al artículo 66.1 a) LGT 1963 «... pues habrá de estarse al criterio general de que interrumpe la prescripción la notificación al interesado de la apertura del expediente sancionador o del inicio de las diligencias para la averiguación de los hechos presuntamente ilícitos». LOZANO CUTANDA, B.: La extinción de las sanciones administrativas y tributarias, Marcial Pons, Madrid,1990, pág. 218.

${ }^{21}$ Expone Pont Mestres que, para Corral Guerrero, el hecho de que la interposición de recurso por el sujeto infractor se le atribuya por ley el efecto de interrumpir el plazo de prescripción, no le acaba de ver de fundamento, porque si la inactividad del derecho de la Administración es lo que tiende a producir la prescripción, la inte- 
La acción del órgano pertinente de la Administración legalmente competente $^{22}$ requiere del conocimiento formal del interesado -aunque ello no significa que deba tener conocimiento material y efectivo de aquélla ${ }^{23}$-, lo que hace que se exija una comunicación notificada en debida forma, pero además se exige que el conocimiento formal lo tenga el interesado, término más amplio que el de sujeto infractor, aunque, a la postre, sólo de éstos se exija la responsabilidad por infracciones, dada la vigencia del principio de responsabilidad por infracciones y sanciones y la manera en que los tipos de infracción se atribuyen exclusivamente a los autores materiales y directos ${ }^{24}$.

Precisamente, en relación con las especialidades que puede presentar el procedimiento sancionador en el ámbito tributario, la primera y más importante es que puede resultar conveniente interpretar con cierta flexibilidad las causas de interrupción de la prescripción de la infracción de modo que no se considere exclusivamente la iniciación strictu sensu del procedimiento sancionador como causa interruptiva de este plazo, sino que se admita que las actuaciones previas en las que se descubre la posible comisión de una infracción interrumpan también este plazo de prescripción. Dado que la LGT contiene una regulación expresa de las causas de interrupción de la prescripción de la acción para sancionar, algún autor opina ${ }^{25}$ que no es

rrupción ha de consistir en una actividad del administrado, ya que no se puede dar una actividad recurrente de la Administración. Partiendo de que el recurso ha de dirigirse contra un acto emanado de la Administración tributaria, la eficacia de la interrupción proviene de dicho acto, que supone el ejercicio de un derecho de la Administración, pero no del acto del recurso. Manifiesta que esta línea de pensamiento la ha advertido SÁINZ DE BuJANDA. Considera que quien recurre no reconoce sino que niega. Pont Mestres, M.: La prescripción tributaria ante el derecho a liquidar y el derecho a recaudar y cuestiones conexas, Marcial Pons, 2008, pág. 27.

${ }^{22}$ Así no resultarían interruptivas las acciones realizadas por Administración Tributaria que no resulte competente en el correspondiente procedimiento sancionador tributario incoado. Por ende, resulta necesario que tanto la Administración como el órgano sean competentes tanto por razón de la materia como del territorio.

${ }^{23}$ Siendo suficiente, por ejemplo, el mero intento de notificación de inicio de las actuaciones y posterior publicación en Boletines Oficiales y edictos (por comparecencia), aunque no se halla recibido materialmente por el obligado tributario-presunto infractor.

${ }^{24}$ Lamoca Pérez, C.: Infracciones... op. cit. pág. 215. Lamoca Pérez, C.: Infracciones... op. cit. pág. 221.

${ }^{25}$ Así Aníbarro Pérez, S. y Sesma Sánchez, B.: Infracciones: ... op. cit. pág. 110. En el mismo sentido vid., MUÑÓZ BAÑOS, C.: Infracciones tributarias y delitos contra la Hacienda Pública, Edersa, Madrid, 1996, pág. 349. En contra de la no aplicación Garberí Llobregat, J. et alii: Procedimiento Sancionador... op. cit. pág. 593.; Pérez Royo, I.: «La prescripción en las actuaciones inspectoras», REDF, Civitas, núm. 96, 1996, pág. 584; DE Miguel CANuto, E.: La prescripción... op. cit. pág. 28; GARcía DE EnTERría, E. y Fernández Rodríguez, T. R.: Curso de Derecho Administrativo. II. Civitas, 2002, pág. 183. 
aplicable lo dispuesto en el artículo 30.2.2. ${ }^{\circ}$ de la Ley 40/2015, de 1 de octubre, de Régimen Jurídico del Sector Público (LRJSP), según el cual, la iniciación del procedimiento sancionador interrumpirá la prescripción pero se reiniciará (reanudará, decía el art. 132.2 LRJPAC) «el plazo de prescripción si el expediente sancionador estuviera paralizado más de un mes por causa no imputable al presunto responsable». Según esta vertiente doctrinal, el plazo de duración del procedimiento sancionador tributario tiene su propia regulación temporal que prevalece, como norma especial, frente a lo dispuesto en este punto en las LPACAP y LRJSP.

Si bien el precepto se refiere a cualquier acción administrativa no debe perderse de vista que, la misma, ha de conducir efectivamente a la imposición de la sanción previa la determinación de la condición de infractor del sujeto agente y del tipo de infracción objeto de la multa, por lo que no sería actuación administrativa susceptible de interrumpir el plazo prescriptivo aquella que se llevara a cabo como mero pretexto administrativo para salvar la inactividad advertida en las actuaciones seguidas para imposición de la sanción (v.gr. trámites, diligencias o proveídos innecesarios o de argucia), de manera que el acto administrativo interruptivo de la prescripción es aquel que, material y tendencialmente, persigue alcanzar la finalidad propia que lo guía $^{26}$, es decir, la imposición de la sanción.

Una segunda especialidad de esta causa de prescripción es que parece existir cierto consenso acerca de que la interrupción del plazo de prescripción tiene efectos instantáneos, esto es, un nuevo plazo de prescripción se reinicia en el mismo momento en el que la interrupción se produce (interrupción instantánea) frente a la posibilidad, por la que podía haber optado el legislador, de extender los efectos de la prescripción hasta que se paralice el acto interruptivo (interrupción de efectos duraderos), al igual que sucede en el ámbito penal y en el administrativo sancionador. Esta forma de regular la interrupción de la prescripción, con efectos instantáneos, no se recoge en el artículo 189 LGT, pero sí se regula en el artículo 68.5 LGT en donde se establece que "producida la interrupción, se iniciará de nuevo el cómputo del plazo de la prescripción» -en este supuesto- a partir de la fecha de la última actuación de la Administración. De cualquier modo, en relación con este aspecto, parece que el hecho de que, tanto en el ámbito sancionador administrativo general como en el tributario, esté previsto un plazo máximo de duración del procedimiento sancionador, hace

\footnotetext{
${ }^{26}$ Aunque lo señala al tratar la prescripción de las obligaciones tributarias, ESEvERRi Martínez, E.: Derecho Tributario. Parte General, Tirant lo Blanch, Valencia, 2011, pág. 233.
} 
innecesaria la previsión de la reanudación del plazo prescriptivo. En efecto, la iniciación del procedimiento interrumpiría la prescripción de la responsabilidad administrativa o tributaria, y a partir de ese momento, comenzaría a correr el plazo -de perención- de seis meses del procedimiento sancionador (art. 211.2.1. ${ }^{\circ}$ LGT). Si este plazo se paraliza por causa imputable a la Administración -que es el supuesto lógico, ya que este procedimiento se impulsa de oficio- y no finaliza en seis meses, las actuaciones no habrán sido válidas y por tanto no habrán interrumpido el plazo inicial de prescripción, sin perjuicio de que el procedimiento no pueda incoarse ex novo. En el supuesto de que finalice en los seis meses previstos, ya no habría posibilidad de interrumpir la prescripción de la responsabilidad derivada de la infracción, pues, y sin perjuicio de la necesidad de firmeza de la misma, lo único que, desde entonces, podría prescribir es la sanción tributaria propiamente dicha.

Por último, en relación con los requisitos que deben cumplir los actos con eficacia interruptiva, hay que diferenciar entre los realizados por la Administración Tributaria y por los administrados; en relación con los primeros, la doctrina, con apoyo en diversas resoluciones administrativas y jurisprudenciales ${ }^{27}$, ha ido delimitando estos requisitos y ha señalado que es preciso que se trate de actos que afecten e impulsen el procedimiento encaminándole hacia la consecución de su resolución, que además, deben ser notificados al sujeto pasivo en la forma legalmente establecida y respecto de un objeto de interrupción determinado y no otro ${ }^{28} \mathrm{y}$ que, lógicamente, deben realizarse dentro del plazo de prescripción. En relación con los segundos, los interesados no pueden interrumpir -con sus propios actosla prescripción mediante acciones conducentes a la imposición de sanción tributaria.

${ }^{27}$ GÉNOVA GaLVÁN, recoge una serie de resoluciones del TEAC y del TS en relación a los actos que tienen y los que no poseen eficacia interruptiva, en GÉNOvA GaLVÁN, A.: ¿La prescripción tributaria», REDF, Civitas, Madrid, núm.57, eneromarzo,1988, pág. 52. También recoge un buen número de sentencias en las que se aclara y delimita este tema, JUAN LOZANO, A. M.: La interrupción de la prescripción tributaria. Análisis de jurisprudencia y doctrina administrativa, Tecnos, Madrid,1993, págs. 99 y ss.

${ }^{28}$ Habrá que tener presente que la interrupción prescripción únicamente procederá respecto del tributo objeto de la acción por la infracción o incumplimiento, y no otro objeto respecto del que no haya actuado la administración, cuyo plazo proseguirá sin interrupción. 


\section{II.B) Realizada con conocimiento formal del interesado}

La claridad del precepto no ofrece dudas, es el acto de comunicación al interesado, y no la fecha de la resolución que se notifica, el que interrumpe el curso de la prescripción, volatilizando el tiempo ya transcurrido. La eficacia de los actos administrativos -también para interrumpir la prescripción- queda demorada hasta su notificación ${ }^{29}$ -art. 39.1 LPACAP-. No basta pues, con que la Administración actúe, es preciso que tal actuación llegue formalmente a conocimiento del interesado para que se interrumpa la prescripción (STS, Sala 3. ${ }^{\mathrm{a}}$, Secc 1. ${ }^{\mathrm{a}}, 31.07 .1989$, FJ. $\left.2 .^{\circ}\right)$.

Los actos de comunicación son instrumentales del derecho de defensa, en la medida en que, gracias al conocimiento por el interesado del acto o resolución que se le notifica, queda asegurado su derecho a intervenir en el procedimiento desde tal momento (mediante alegaciones, pruebas, entre otros), y a interponer los recursos procedentes contra las resoluciones que se dicten. De ahí que, las notificaciones, deban ser realizadas por el órgano administrativo con todo el cuidado y respeto ${ }^{30}$ de las normas que regulan dichos actos de comunicación, dado que no son un formalismo, sino una garantía para las partes en el procedimiento y una carga que corresponde llevar a cabo al órgano administrativo (SsTC 113/2001, 19/2004; STS 30.04.1987) Precisamente la finalidad instrumental de la notificación como vehículo de información para permitir al interesado la impugnación de los actos

${ }^{29}$ Además, sólo las notificaciones practicadas regularmente tienen efectos prescriptivos; no así las de los actos que estén afectados de nulidad ni las notificaciones irregulares o nulas, como podría ser la efectuada por edictos sin que se den los presupuestos y requisitos para ello. Las SsTS 5.12.1983, 31.01.1989 afirman que la prescripción no puede interrumpirse por la práctica de notificaciones irregulares, ni por las actividades de la Administración no materializadas en actos administrativos concretos, estimando irregulares y no aptas para interrumpir la prescripción, todas una serie de notificaciones por falta de indicación de los recursos procedentes, por haberse hecho fuera del domicilio social de la entidad deudora, y a persona cuya relación con dicha entidad no consta, como tampoco consta su identidad. De Diego DíEz, L. A.: Prescripción y caducidad en el Derecho administrativo sancionador, Bosch, Barcelona, 2006, págs. 92-94.

${ }^{30}$ Real Decreto 1829/1999, de 3 de diciembre, por el que se aprueba el Reglamento por el que se regula la prestación de los servicios postales, en desarrollo de lo establecido en la Ley 24/1998, de 13 de julio, del Servicio Postal Universal y de Liberalización de los Servicios Postales (RSP). Artículo 40. Admisión de notificaciones de órganos administrativos y judiciales (STS 8.06.2004). La admisión de notificaciones por el operador al que se ha encomendado la prestación del servicio postal universal requiere que en el envío conste la palabra «Notificación», y, debajo de ella y en caracteres de menor tamaño, el acto a que se refiera (citación, requerimiento, resolución) y la indicación «Expediente núm...» o cualquier otra expresión que identifique el acto a notificar. Estos envíos se acompañarán del documento justificativo de su admisión. 
administrativos, ha llevado a exigir, con mayor rigor, el cumplimiento de sus específicas formalidades legales. Tal rigor procedimental no tiene su razón de ser en un exagerado formulismo, sino en constituir una pieza clave para la proscripción de la indefensión ${ }^{31}$ y la garantía del derecho a la tutela judicial efectiva que consagra el art. 24 de la Constitución ${ }^{32}$. Es, por consiguiente, la Administración quien está gravada con la carga procesal de acreditar la regularidad de las notificaciones, y no el imputado con la carga inversa de probar su irregularidad (STS 12.05.1997), aunque apareciendo en el expediente el acto de comunicación adecuadamente documentado, entonces sí, será el recurrente quien tendrá que hacer frente a la carga de probar que, pese a la apariencia, la notificación no se ha producido conforme a Derecho (STSJ Baleares 18.06.1996). Con todo, no puede olvidarse que, conforme a lo dispuesto en el art. 40.3 LPACAP, las notificaciones irregulares o defectuosas son eficaces y surten sus efectos propios -incluido el interrumpir la prescripción-, a partir de la fecha en que el interesado realice actuaciones que supongan el conocimiento del contenido y alcance de la resolución o interponga cualquier recurso que proceda, aunque de dicho precepto no se infiere, desde luego, que la eficacia de la notificación del acto administrativo se retrotraiga a la fecha en la que el mismo fue defectuosamente notificado, pues la literalidad del precepto no deja duda acerca de que el período para recurrir se abre desde que los interesados se dan por notificados, bien porque expresamente fijan tal fecha o, si no lo hacen, se tendrá por tal la de interposición del recurso contra la resolución defectuosamente notificada ${ }^{33}$.

El régimen de notificaciones en materia de procedimientos sancionadores tributarios lo encontramos recogido en los artículos 178, 207,

${ }^{31}$ Recordemos que la Administración Tributaria puede imponer la notificación mediante dirección electrónica a quienes no siendo persona física, con ciertas excepciones para ciertos colectivos de obligados persona física (art. 115 bis RD 1065/2007, de 27 de julio, por el que se aprueba el Reglamento General de las actuaciones y los procedimientos de gestión e inspección tributaria y de desarrollo de las normas comunes de los procedimientos de aplicación de los tributos [RGGI]). Sobre este tipo de notificaciones vía dirección electrónica, vid. art. 38 RD 1671/2009, de 6 de noviembre.

32 SsTS 25.02.1998.

${ }^{33}$ STSJ Madrid 16.05.2000; Para que los envíos de las notificaciones de órganos administrativos y judiciales sean admitidos por la Entidad Pública Empresarial Correos y Telégrafos y surtan efectos probatorios en el procedimiento administrativo o judicial, se requiere, conforme a los establecido en el art. 40 RD 1829/1999 que conste la palabra "Notificación» y, debajo de ella y en caracteres de menor tamaño, el acto a que se refiera (citación, requerimiento, resolución) y la indicación «Expediente núm....» o cualquier otras expresión que identifique el acto a notificar. La defectuosa identificación del acto puede dar lugar a una notificación sin validez alguna. DE DIEGo DíEz, L. A.: ... op. cit. pág. 100; Así la STS 28.10.2004. 
208.4 y 211.2 LGT, que remiten a los artículos 109 a 112 LGT. Entendemos que la remisión ${ }^{34}$ del artículo 109 a los artículos 39 a 46 y DA $1 .^{a} 2{ }^{\circ}$ LPACAP prevalece sobre los preceptos 114 a 115 ter RGGI, no sólo por que la LGT no remite directamente a su reglamento que la desarrolle con carácter preferente, sino porque su propio artículo 1 $\mathrm{RGGI}^{35}$ así lo restringe.

Cuando la notificación se practique en el lugar señalado por el interesado y éste no se hallare presente en el momento de practicarla, puede hacerse cargo de la misma cualquier persona mayor de catorce años que se encuentre en dicho domicilio y haga constar su identidad (arts. 42.2 LPACAP y 109 LGT). Ya en el propio ámbito administrativo, se ha venido admitiendo, las personas legitimadas para la recepción de la notificación, que se recogen en el art. 111.1 LGT, así los porteros de fincas, empleados de comunidades de propietarios, aún cuando éstos no residan en el inmueble ${ }^{36}$, entendiendo que en estos casos si que resultará necesario hacer constar «dicha condición». En cualquier caso, deberá constar en el aviso de recibo que se devuelve a la Administración, la fecha, identidad, número de documento nacional de identidad (DNI) o del documento que lo sustituya, y firma de la persona que se haga cargo de la notificación, así como firma y número de identificación del empleado del operador postal (art. 41.3 RSP $)^{37}$, no siendo suficiente una firma ilegible sin expresar ni el nom-

${ }^{34}$ Artículo 109 LGT. Notificaciones en materia tributaria. El régimen de notificaciones será el previsto en las normas administrativas generales con las especialidades establecidas en esta sección.

${ }^{35}$ Artículo 1 RGGI. Ámbito de aplicación. 1. Este reglamento regula la aplicación de los tributos en desarrollo de la Ley 58/2003, de 17 de diciembre, General Tributaria. Este reglamento será de aplicación a la gestión recaudatoria en lo no previsto en el Reglamento General de Recaudación, aprobado por el Real Decreto 939/2005, de 29 de julio. Lo dispuesto en este reglamento se entenderá sin perjuicio de lo previsto en la normativa propia de cada tributo. 2. Este reglamento será de aplicación en los términos previstos en el artículo 1 de la Ley 58/2003, de 17 de diciembre, General Tributaria. 3. Este reglamento se aplicará al procedimiento sancionador en materia tributaria en lo no previsto por sus normas específicas de desarrollo y por las normas reguladoras del procedimiento sancionador en materia administrativa.

${ }^{36}$ STSJ Madrid 21.1.1998; Por todas, la STS 17.07.1997.

${ }^{37}$ A luz del FJ 5. ${ }^{\circ}$ de la STS de 20.07.2012, concluimos con la anterior normativa administrativa, que ciertamente el artículo 59, apartado $2 .^{\circ}$, de la LRJPAC (hoy aparentemente idéntica en el art. 42.2 LPACAP), era claro en el sentido de que, a diferencia de la regulación anterior, de la que se aparta, no requería para la eficacia de la notificación domiciliaria que en la diligencia correspondiente se hicieran constar expresamente datos como el parentesco, la condición o la razón de permanencia de quien se encontraba en el domicilio en el que la notificación se producía y recibía el acto notificado; tan sólo requería que quien se hiciera cargo de la notificación dejara constancia de su identidad. Así lo precisaba la sentencia de esta Sala de 24 de mayo de 2010 (Casación para unificación de doctrina n. ${ }^{\circ}$ 318/2005 ), donde se puntualiza (FJ 3.․) 
bre y apellidos de quien se haga cargo de la notificación, ni tampoco su DNI (STSJ País Vasco 12.06.1998). La firma de quien se hace cargo de la notificación no resulta imprescindible, así si aún recogiendo la notificación e identificándose, se niega a firmar su recepción, basta con que tal circunstancia se haga constar por el empleado de correos, siendo válida y efectiva la notificación así entregada, teniendo esta carácter de 'constancia fehaciente de su recepción' (art. 39 RSP) si se efectúa por los empleados de la entidad pública empresarial Correos y Telégrafos, no así la de los demás operadores postales, cuyos efectos se regirán por las normas de derecho privado (STSJ Andalucía 22.05.2001). En caso de que la comunicación no llegue a materializarse porque la misma se rechaza, la situación de indefensión que por ello pueda generarse no es imputable a la Administración, sino a quien obstaculizó su recepción (STS 4.05.1998), pues las resoluciones recaídas en procedimientos seguidos inaudita parte, no suponen vulneración alguna cuando el afectado no ha puesto la debida diligencia

que: «cuándo en el domicilio designado por el interesado o su representante a efectos de recibir las oportunas y correspondientes notificaciones no esté aquél presente, la cédula puede ser entregada a cualquier persona que se encuentre en el mismo y haga constar su identidad, sin que el art. 59.2 de la Ley 30/92 exija que se haga constar la condición del receptor de la notificación, ya que solo obliga a hacer constar su identidad». Obvio es que cuando la norma exige que se haga constar la identidad del receptor, ello implica que se deje constancia expresa de tal identidad en la diligencia de notificación, en términos que permitan identificar de forma indubitada a esa persona que la ha recogido. Partiendo de esta base, si la persona destinataria del acto notificado discute la eficacia de la notificación, justamente bajo el argumento de que quien consta como receptor de dicha notificación en la diligencia correspondiente es una persona inexistente o desconocida, o sin relación alguna profesional, personal, familiar o de cercanía con aquel a quien la notificación se dirige, o que por cualquier otra circunstancia no estaba en condiciones de hacerse cargo de la notificación de una forma operativa y eficaz, deberá aportar datos suficientes para sustentar semejante afirmación, no bastando la mera alegación de que así ocurre; pues el artículo 59.2 LRJPAC, de tanta cita, partía de la presunción de que quien se encuentra en un domicilio tiene una relación de vinculación, afinidad o confianza con el titular del mismo en grado suficiente como para hacerse cargo de las notificaciones que a éste se le dirigen, y aun cuando ésta es una presunción iuris tantum, es carga que pesa sobre el titular del domicilio y destinatario de la notificación desvirtuar tal presunción mediante la aportación de datos y elementos de prueba que permitan contrarrestarla. Sin perder de vista que el juicio sobre la eficacia de las notificaciones se encuentra estrechamente ligado a las circunstancias concretas del caso, lo que comporta inevitablemente un importante grado de casuismo en la materia, habida cuenta que en esta materia de notificaciones lo que ha de valorarse es la indefensión material y efectiva, y no la meramente retórica y formal, dado el principio antiformalista y el principio general de buena fe que la rigen ( STS de 26 de mayo de 2011, recurso de casación n. ${ }^{\circ}$ 5423/2008), si bien puede apuntarse, siempre con carácter general, y por tanto con supeditación a las circunstancias de cada caso, no cabe que el interesado alegue que la notificación se produjo en lugar o a persona improcedente cuando recibió sin problemas y sin reparo alguno otras recogidas en el mismo sitio o por la misma persona ( STS de 26 de mayo de 2011, cit.). 
en la defensa de sus derechos e intereses, bien colocándose al margen del proceso mediante una actitud pasiva con el fin de obtener una ventaja de esa marginación, bien cuando pueda deducirse que poseía un conocimiento extraprocesal de la existencia del litigio en el que no fue personalmente emplazado. Equiparable al interesado es su cónyuge, de modo que si éste rechaza la notificación, aún cuando se desconozca el régimen económico matrimonial, sí puede entenderse que la vida en común (arts. 68 y 69 del Código Civil -CCiv-) y la obligación que ambos tienen de actuar en interés de la familia (art. 67 CCiv), son razones suficientes como para inferir que el rechazo de la notificación fue conocido y aceptado por el propio destinatario, a los efectos de aplicar el art. 41.5 LPACAP (STSJ Andalucía 24.10.1997). La notificación rehusada, no se tendrá por practicada y carecerá de virtualidad para interrumpir la prescripción, cuando no se hayan hecho constar las circunstancias en que se produjo el rechazo (STSJ Madrid 6.7.2000 ${ }^{38}$, cuando no conste la firma del agente o funcionario notificador (STSJ Aragón 14.3.1998) o, incluso, cuando conste pero sea ilegible (STSJ País Vasco 21.10.1998). Hemos de concretar que el rechazo de la notificación puede ser realizado, únicamente, por el interesado o por su representante, para que se tenga por efectuada la misma (art. 111.2 LGT) ${ }^{39}$, en caso de realizarse por cualquier otra persona de entre las citadas en el apartado $1 .^{\circ}$ del art. 111 LGT -cualquier persona que se encuentre en dicho lugar o domicilio y haga constar su

${ }^{38}$ Para DE DiEgo DíEz en los casos en que el interesado o su representante no esté dispuesto a identificarse y firmar la diligencia, se abren dos alternativas: dar carácter probatorio, al menos, iuris tantum a la certificación firmada por el agente notificador (art. 43.a RSP en relación al art. 39 RSP); o bien realizar un segundo intento de notificación, conforme a lo previsto por el art. $42.4 .^{\circ}$ y $5 .^{\circ} \mathrm{RSP}$, y si en esta segunda ocasión también se niega a aceptarla y a manifestar por escrito dicha circunstancia, se dará entonces por rehusada o rechazada a los efectos del art. 59.3 LRJPAC (renumerado como art. 59.4 LRJPAC por el art. 68.2 de la Ley 24/2001, de 31 de diciembre) [hoy art. 41.5 LPACAP]. De esta segunda opinión es el autor. DE DiEGo DíEz, L. A.: ... op. cit. págs.107-108.

${ }^{39}$ Artículo 22 Ley 43/2010, de 30 de diciembre, del servicio postal universal, de los derechos de los usuarios y del mercado postal. Principios y requisitos de la prestación del servicio postal universal. 4. La actuación del operador designado gozará de la presunción de veracidad y fehaciencia en la distribución, entrega y recepción o rehúse o imposibilidad de entrega de notificaciones de órganos administrativos y judiciales, tanto las realizadas por medios físicos, como telemáticos, y sin perjuicio de la aplicación, a los distintos supuestos de notificación, de lo dispuesto en la Ley 30/1992, de 26 de noviembre, de Régimen Jurídico de las Administraciones Públicas y del Procedimiento Administrativo Común.

Las notificaciones practicadas por los demás operadores postales surtirán efecto de acuerdo con las normas de derecho común y se practicarán de conformidad con lo previsto en el artículo 59 de la Ley 30/1992, de 26 de noviembre, de Régimen Jurídico de las Administraciones Públicas y del Procedimiento Administrativo Común. 
identidad (y no sea el propio interesado o su representante) ${ }^{40}$, así como los empleados de la comunidad de vecinos o de propietarios- la notificación no podría entenderse realizado el rechazo, pues el precepto sólo admite esta forma de notificación con carácter excepcio$\mathrm{nal}^{41}$, siendo su asiento una ficción jurídica ${ }^{42}$, por lo que debe realizarse una interpretación restrictiva del supuesto. Así, en caso de que el interesado o su representante no se encuentren en el domicilio, y nadie que se encuentre en el domicilio quiera asumir dicha carga, lo correcto es dar la notificación por fallida ${ }^{43}$ (STSJ Comunidad Valenciana 30.03.2000). Entendemos que no resulta aplicable la regulación establecida por el art. 42.5 RSP cuando, tras un primer intento de notificación sin que esté presente el interesado o su representante -o estando rehúsa su recepción-, se efectúa un segundo que resulta infructuoso por no encontrase presente el interesado o su representante, en cuyo caso no cabe tener por rehusada la notificación, por mor de la especialidad del art. 111.2 LGT. En el caso de personas jurídicas, el rechazo, entendemos, sólo podrá ser efectuado por su representante, y no por un empleado de la misma según cita el art. 44.2 RSP, excepción hecha de las personas jurídicas públicas en cuyo caso sí resulta bastante que lo realice un empleado, el encargado de la oficina de registro de entrada (electrónico) general o auxiliar de cada Entidad (art. 16 LPACAP).

Por remisión del artículo 208.4. ${ }^{\circ}$ LGT al artículo 109 de la LGT $^{44}$, en lo que allí no se contemple, debemos estar al tenor del artículo 40.2. ${ }^{\circ}$ LPACAP, en lo relativo al plazo de las notificaciones de las resoluciones y notificaciones con contenido defectuoso ${ }^{45} \mathrm{o}$ incomple-

${ }^{40}$ Esto mismo indica el art. 41.2 RSP y con mayor rotundidad explicita el art. 24.6. ${ }^{\circ}$ Ley $43 / 2010$, de 30 de diciembre.

${ }^{41}$ SsTSJ País Vasco 28.07.1998 y 30.3.2000; STSJ Aragón 8.10.2002.

${ }^{42}$ STSJ Murcia 10.11.1999.

43 De Diego DíEz, L. A.: ... op. cit. pág. 110; así el art. 42 apartado $4 .^{\circ} 6 .^{\circ}$ RSP.

${ }^{44}$ Artículo 109 LGT. Notificaciones en materia tributaria. El régimen de notificaciones será el previsto en las normas administrativas generales con las especialidades establecidas en esta sección; Ampliamente desarrolla las notificaciones en materia administrativa Linde Paniagua, E.: Fundamentos de Derecho Administrativo. Del Derecho del Poder al Derecho de los ciudadanos, COLEX-Uned, Madrid,2009, págs. 326 a 330.

${ }^{45}$ A diferencia de lo que acontecía en la anterior versión, la LGT guarda silencio sobre las notificaciones defectuosas, respecto de las que la jurisprudencia constitucional ha señalado que no siempre provocan indefensión, sino solamente cuando los fallos impiden el cumplimiento de su finalidad, tendente a comunicar la resolución en términos que permitan mantener las alegaciones o formular los recursos pertinente contra la resolución. Martínez LaGo, M. A. y García DE LA Mora, L.: Lecciones ... op. cit. pág. 396; Con esta omisión el legislador asume el planteamiento de la jurisprudencia sobre el particular, que ha sido muy estricta en relación a los efectos de las notificaciones defectuosas, y su mera subsanación por el paso del tiempo, además 
to, de modo que «toda notificación deberá ser cursada dentro del plazo de diez días a partir de la fecha en que el acto haya sido dictado ${ }^{46}$, y deberá contener el texto íntegro de la resolución, con indicación de si es o no definitivo en la vía administrativa, la expresión de los recursos que procedan, en su caso, en vía administrativa y judicial, órgano ante el que hubieran de presentarse y plazo para interponerlos, sin perjuicio de que los interesados pueden ejercitar, en su caso, cualquier otro que estimen procedente».

ello supone un plus de eficacia injustificado...A partir de ahora, resultará de aplicación el art. 58.3 LRJPAC (hoy art. 43.2 LPACAP). PALAO TABOADA, C.: Comentario sistemático a la nueva Ley General Tributaria, CEF, Madrid, 2004, pág. 343.

${ }^{46} \mathrm{El}$ incumplimiento de dicho plazo no puede considerarse que determina la invalidez de la notificación, sino que es una mera irregularidad que habrá que enjuiciar a la luz del artículo 43.3 LPACAP (con anterioridad art. 63.3. ${ }^{\circ}$ LRJPAC); La STS de 27 de mayo de 1992 falló que «dicho plazo ... es un mandato que constituye una obligación para la oficina administrativa, pero su incumplimiento no invalida la notificación al interesado, salvo prueba en contrario que evidencia cualquier clase de daño por el retraso entre la fecha del acto y la de su notificación, ya que es a partir de esta última, y sólo a partir de ella, cuando surgen derechos y obligaciones para el administrado derivadas del primero». En igual sentido la STS de 17 de febrero de 1997 sentencia que «la circunstancia de haberse efectuado la notificación una vez transcurrido el plazo de diez días no impone la anulación de la notificación hecha fuera de dicho plazo, ya que el notificado no se ve afectado por la resolución, no está obligado a su cumplimiento, ni ve correr los plazos legales para interponer los correspondientes recursos, sino desde el día de la notificación. La naturaleza de este plazo, pues, como la mayor parte de los fijados para realizar las actuaciones administrativas, no implica la anulación de la notificación realizada después del transcurso de los diez días, en razón de que el acto solamente surte sus efectos desde dicha notificación, cualquiera que sea el momento en que ésta se realiza»; El art. 58.2 LRJPAC (hoy art. 40.2 LPACAP) resulta de aplicación en el ámbito sancionador tributario de conformidad con el apartado 3 del art. 208 (actual apartado 4) de la Ley 58/2003...Dado que en la Ley General Tributario no existe previsión alguna sobre esta materia, será de aplicación lo dispuesto en el citado art. 58 (hoy art. 43.2 LPACAP).(DGT, 10 de junio de 2005); ¿Qué sucede en aquellos casos en que el acto administrativo está redactado en una de las dos lenguas oficiales en la Comunidad Autónoma y el interesado solicita que se le envíen las notificaciones en la otra lengua? Debemos distinguir en aquellos casos en que se trate de una primera notificación en la que todavía el interesado no ha podido solicitar que se el comunique en otra lengua, y aquellos otros en que a pesar de haber solicitado expresamente que las comunicaciones se realicen en una determinada lengua la Administración desoye la petición del interesado. En cuanto al primer caso, la STSJ de Baleares de 9 de mayo de 1997, estima los efectos interruptivos de la prescripción (lo que no puede hacer es aprovecharse de ello para desplazar hasta el momento inicial -los efectos de la solicitud de cambio de lengua- la consideración de la actuación administrativa con conocimiento de la denunciada al efecto de interrumpirse sólo entonces la prescripción de la acción para sancionar. Respecto al segundo caso estaríamos ante una clara vulneración de los derechos lingüísticos del interesado y del régimen de cooficialidad existente en el territorio de que se tratase. Por último, al examinar esta vulneración de derechos debería tenerse en cuenta el principio de buena fe y si ha causado efectivamente indefensión al interesado para evitar abusos. Aguado I Cudolà, V.: Prescripción... op. cit. págs. 40 y 41. 
Las notificaciones que, conteniendo el texto íntegro del acto, omitiesen alguno de los demás requisitos previstos en el apartado anterior surtirán efecto a partir de la fecha en la que el interesado realice actuaciones que supongan el conocimiento del contenido y alcance de la resolución o acto objeto de la notificación, o interponga cualquier recurso que proceda. Este precepto no resulta en modo alguno incompatible con lo dispuesto en la Ley General Tributaria, que resulta válido incluso para el procedimiento inspector y de comprobación ${ }^{47}$. (art. 40.3 LPACAP).

El lugar donde practicar dicha notificación se refleja de modo específico en el artículo 110.2. ${ }^{\circ}$ LGT, que regula que, en los procedimientos iniciados de oficio, la notificación podrá practicarse en el domicilio fiscal del obligado tributario ${ }^{48}$ o su representante ${ }^{49}$, en el centro de trabajo $^{50}$, en el lugar donde se desarrolle la actividad económica ${ }^{51}$ o en cualquier otro adecuado a tal fin ${ }^{52}$. Por último, la regulación de las per-

${ }^{47}$ Collado Yurrita, M. A.(Dir.); Luchena Mozo, G. M.(coord.), et alii: Derecho Tributario. Parte General, Atelier, Barcelona, 2007, pág. 302.

${ }^{48}$ Regulado en el artículo 48 LGT y art. 113 RGGI.

${ }^{49}$ Regulado en los artículos 45 a 47 LGT y arts. 110 a 112 del RGGI.

${ }^{50} \mathrm{El}$ art. Real Decreto Legislativo 2/2015, de 23 de octubre, por el que se aprueba el texto refundido de la Ley del Estatuto de los Trabajadores (con anterioridad art. 1.5 del RDLg. 1/1995, de 24 de marzo), norma «A efectos de esta Ley se considera centro de trabajo la unidad productiva con organización específica, que sea dada de alta, como tal, ante la autoridad laboral. En la actividad de trabajo en el mar se considerará como centro de trabajo el buque, entendiéndose situado en la provincia donde radique su puerto de base. » En igual sentido el art. 44.5, aunque el art. 40 prevé que puedan ser, incluso, móviles e itinerantes. El art. 50.8 del RD 1165/1995, de 7 de julio, por el que se aprueba el Reglamento de los Impuestos Especiales, cita centro de gestión y control de dicho establecimiento.

${ }^{51}$ No existe propiamente un concepto que defina actividad económica, sin embargo, algunas alusiones se dejan entrever en la LGT, en los artículos $42.1 .^{\circ} \mathrm{c}$ ), 43.1. ${ }^{\circ}$ ), $\left.48.2 .^{\circ} \mathrm{a}\right), 82.1 .^{\circ}$, y $\left.82.2 .^{\circ} \mathrm{b}\right)$. Tampoco dicho precepto no refiere a actividad principal o secundaria. Una definición bastante apropiada podemos encontrarla en el artículo 113 RD 1065/2007, que define «se podrá considerar que las personas físicas desarrollan principalmente actividades económicas cuando más de la mitad de la base imponible general del Impuesto sobre la Renta de las Personas Físicas del año anterior proceda de rendimientos netos de actividades económicas o cuando, no habiéndose alcanzado ese porcentaje en dicho año, se haya alcanzado durante cada uno de los tres años anteriores. A efectos de lo previsto en este artículo, se entenderá por actividades económicas las realizadas por los empresarios y profesionales en los términos previstos en la Ley 37/1992, de 28 de diciembre, del Impuesto sobre el Valor Añadido; el art. 60.4.1.e) RD 2538/1994, de 29 de diciembre, por el que se dicta normas de desarrollo relativas al Impuesto General Indirecto Canario y al Arbitrio sobre la Producción e Importación en las islas Canarias, creados por la Ley 20/1991, de 7 de junio (IGIC), explicita sin definir el centro de sus intereses económicos.

${ }^{52}$ Entendemos que ese fin es el cometido propio del acto de comunicación que pretende la notificación. 


\section{sonas legitimadas para recibir las notificaciones ${ }^{53}$ y de la notificación edictal $^{54}$ o por comparecencia ${ }^{55}$ (art. 112 LGT) es objeto de normación}

${ }^{53}$ Se regula en el art. 111 LGT, del que debemos indicar que resulta redundante que exprese dos veces en un mismo párrafo «el domicilio fiscal del obligado o su representante». A mayor abundamiento, precisa el RD 1829/1999, de 3 de diciembre, de 3 de diciembre, por el que se aprueba el Reglamento por el que se regula la prestación de los servicios postales, en desarrollo de lo establecido en la Ley 24/1998, de 13 de julio, del Servicio Postal Universal y de Liberalización de los Servicios Postales (hoy Ley 43/2010, de 30 de diciembre, del servicio postal universal, de los derechos de los usuarios y del mercado postal, de la que resaltamos por su importancia los arts. 14, 16, 17, 22.4. ${ }^{\circ}, 23$, 24 y 25), en su artículo 41.1. ${ }^{\circ}$ " 1 . Los requisitos de la entrega de notificaciones, en cuanto a plazo y forma, deberán adaptarse a las exigencias de la Ley 30/1992, de 26 de noviembre, de Régimen Jurídico de las Administraciones Públicas y del Procedimiento Administrativo Común, en la redacción dada por la Ley 4/1999, de 13 de enero, de modificación de aquélla sin perjuicio de lo establecido en los artículos siguientes (hoy Ley 39/2015, de 1 de octubre, LPACAP). 2. Cuando se practique la notificación en el domicilio del interesado y no se halle presente éste en el momento de entregarse dicha notificación, podrá hacerse cargo de la misma cualquier persona que se encuentre en el domicilio y haga constar su identidad. 3. Deberá constar la fecha, identidad, número del documento nacional de identidad o del documento que lo sustituya y firma del interesado o persona que pueda hacerse cargo de la notificación en los términos previstos en el párrafo anterior, en la documentación del empleado del operador postal y, en su caso, aviso de recibo que acompañe dicha notificación, aviso en el que el empleado del operador postal deberá hacer constar su firma y número de identificación.». La LGT amplía las personas legitimadas para recepcionar la notificación.

Una particularidad se regula en el art. 114.2. ${ }^{\circ}$ RD 1065/2007 que norma «2. En el supuesto de notificaciones en apartados postales establecidos por el operador al que se ha encomendado la prestación del servicio postal universal, el envío se depositará en el interior de la oficina y podrá recogerse por el titular del apartado o por la persona autorizada expresamente para retirarlo. La notificación se entenderá practicada por el transcurso de 10 días naturales desde el depósito del envío en la oficina». Este último apartado podría contravenir lo dispuesto en los arts. 109 y 112 LGT, lo previsto como medios de notificación regulados en el art. 40 y 41 LPACAP y el modo de actuar en caso de que intentada la notificación no se hubiere podido practicar del art. 44 LPACAP, al no venir legalmente regulado y comportar un efecto desfavorable para el particular. Hubiera resultado lícito si se hubiera considerado un medio o intento más de notificación, al modo del aviso de llegada previsto en el 114.1. ${ }^{\circ}$. $^{\circ}$ párrafo RD 1065/2007. En desarrollo de dicho precepto mostramos que el artículo 35 RD 1829/1999 prevé: «Entrega de envíos postales en apartados. El operador al que se ha encomendado la prestación del servicio postal universal podrá establecer apartados para la entrega de envíos postales a las personas físicas, jurídicas, públicas o privadas. El resto de los operadores postales podrán establecer también apartados postales en sus dependencias para los envíos postales que no pertenezcan al ámbito de reserva del operador al que se ha encomendado la prestación del servicio postal universal. El apartado de envíos se hará en casilleros y, por razones justificadas del volumen, la densidad de los envíos postales o la naturaleza de los mismos, en el interior de las oficinas. Los envíos postales apartados en el interior de las oficinas serán entregados al titular del apartado o persona autorizada expresamente»; JIMÉNEZ IBÁÑEZ estima que debemos distinguir entre rechazo de la notificación efectuado por el sujeto infractor u obligado tributario en cuyo caso se le tendrá por notificado, y el rechazo llevado a cabo por otra persona distinta que se encuentre en su domicilio familiar, en este caso, se considerará como un mero intento de notificación. Collado Yurrita, M. A., et alii: Derecho Tributario... op. cit. pág. 303.

${ }^{54}$ Arts. 43 y 46 LPACAP.

${ }^{55}$ Vid. formalidades previstas para dicha notificación en el art. 40 RD 1671/2009, de 6 de noviembre. Artículo 40. Notificación por comparecencia electrónica. 1. La 
propia tributaria, no resultando de aplicación la administrativa común en lo que contradiga lo allí legislado ${ }^{56}$. Por último, las notificaciones telemáticas ${ }^{57}$ se regulan en los artículos 41,42 y 43 y en la Disposición Adicional 3. ${ }^{\mathrm{a}}$ LPACAP, así como en los artículos 115 bis y ter $\mathrm{RGGI}^{58}$, y en los artículos 32 a 40 Real Decreto 1671/2009, de 6 de noviembre, por el que se desarrolla parcialmente la Ley 11/2007, de 22 de junio, de acceso electrónico de los ciudadanos a los servicios públicos, en la medida que se estime vigente ${ }^{59}$, y en la medida que no se estimen derogados o se contraponga a la LPACAP.

notificación por comparecencia electrónica consiste en el acceso por el interesado, debidamente identificado, al contenido de la actuación administrativa correspondiente a través de la sede electrónica del órgano u organismo público actuante. 2. Para que la comparecencia electrónica produzca los efectos de notificación de acuerdo con el artículo 28.5 de la Ley 11/2007, de 22 de junio, se requerirá que reúna las siguientes condiciones: a) Con carácter previo al acceso a su contenido, el interesado deberá visualizar un aviso del carácter de notificación de la actuación administrativa que tendrá dicho acceso. b) El sistema de información correspondiente dejará constancia de dicho acceso con indicación de fecha y hora.

${ }^{56}$ En la jurisprudencia constitucional se ha declarado que si la Administración, que debe emplazar personalmente al sujeto, no lo hace, pese a tener conocimiento - $\mathrm{O}$, al menos, evidente posibilidad de adquirirlo- del verdadero domicilio de aquél, no estaría actuando con la diligencia debida que le es exigible, generando una situación de indefensión constitucionalmente relevante si le impide ejercer su derecho de defensa en el procedimiento sancionador. La Administración no puede limitarse a proceder a la notificación edictal sin una mínima actividad indagatoria en oficina y registros públicos para intentar determinar un domicilio de notificaciones alternativo, en su caso, en que poder notificar personalmente (SsTC 158/2007, de 2 de julio-FJ 2. ${ }^{\circ}-$, y 128/2008, de 27 de octubre -FJ 2. ${ }^{\circ}$...Cuando el art. 111 LGT refiere a personas legitimadas para recibir las notificaciones, permite su recepción a «empleados de la comunidad de vecinos o de propietarios donde radique», lo que puede resultar excesivo y presuponer relaciones de conocimiento que no tiendan a acreditarse en la realidad. MARTínEz LAGO, M. A. y GARCía DE LA MoRA, L.: Lecciones... op. cit. págs. 397 y 398; Por lo tanto, lo más correcto y consecuente con la idea de seguridad jurídica es que el órgano notificador procure realizar la notificación tributaria, siempre que sea posible, en el domicilio fiscal del obligado tributario. ESEVERRI ..., 2011, op. cit., pág. 320.

${ }^{57}$ Se echa de menos la expresa regulación en la LPACAP o LGT de la modificación del medio de notificación, como hace, transitoriamente, el art. 37 RD 1671/2009, de 6 de noviembre.

${ }^{58}$ Según el RGGI la notificación realizada en primer lugar produce efectos prevalentes sobre la realizada ulteriormente, y ello resulta válido con independencia que se realice en sede electrónica voluntaria, mediante dirección electrónico o en formato papel (arts. $42.1 .^{\circ}$ y $3 .^{\circ}$ LPACAP y art. 115 ter RGGI). En ese sentido el art. 36.5 RD $1671 / 2009$, de 6 de noviembre.

${ }^{59}$ Sus requisitos reglamentarios en el ámbito tributario se regulan en el artículo 12 del Real Decreto 209/2003, de 21 de febrero, por el que se regulan los registros y las notificaciones telemáticas, así como la utilización de medios telemáticos para la sustitución de la aportación de certificados por los ciudadanos, y en la Orden PRE/878/2010, de 5 de abril, por la que se establece el régimen del sistema de dirección electrónica habilitada previsto en el artículo 38.2 del Real Decreto 1671/2009, de 6 de noviembre. Recordemos que los arts. 35, 36 y 39 se derogan por la disposición derogatoria única.2.g) de la Ley 39/2015, de 1 de octubre. Si bien, de acuerdo con lo 
También es posible la notificación edictal ${ }^{60}$, aunque con el propio carácter residual al que cabe conferirle, pues no deja de ser una ficción ${ }^{61}$ legal que los administrados tengan conocimiento de las resoluciones notificadas a través de este medio -Boletín Oficial del Estado, y potestativamente tablones de edictos de oficinas de la Administración Tributaria del último domicilio fiscal conocido o consulado o sección consultar de la Embajada correspondiente-. A nadie se le oculta que la posibilidad de que el interesado ejercite una real y eficaz defensa se debilita seriamente ante una notificación edictal ${ }^{62}$. Por ello, la Administración sólo está habilitada para acudir al uso de los edictos, como última solución, cuando haya agotado previamente todas aquellas otras modalidades de comunicación que aseguren en mayor medida la recepción por el destinatario de la correspondiente notificación $^{63}$ (arts. 41.3.2. ${ }^{\circ}$ y 44 LPACAP), y que, por esto mismo, garanticen, también en mayor medida, la posibilidad de ejercer el derecho de defensa (STC 181/2003), lo que implica un especial deber de diligencia del órgano administrativo en la realización de los actos de comunicación (STC 138/2003), pues las Administraciones cuentan con acceso información suficiente -propia o ajena- para que les sea exigible

dispuesto en la disposición final 7 LPACAP, esos artículos se mantendrán en vigor hasta que produzcan efectos las previsiones de la citada ley relativas a la materia que se deroga.

${ }^{60}$ Art. 112.1.3. ${ }^{\circ}$ LGT. La publicación en el «Boletín Oficial del Estado» se efectuará los lunes, miércoles y viernes de cada semana. Estos anuncios podrán exponerse asimismo en la oficina de la Administración tributaria correspondiente al último domicilio fiscal conocido. En el caso de que el último domicilio conocido radicara en el extranjero, el anuncio se podrá exponer en el consulado o sección consular de la embajada correspondiente. 2. En la publicación constará la relación de notificaciones pendientes con indicación del obligado tributario o su representante, el procedimiento que las motiva, el órgano competente de su tramitación y el lugar y plazo en que el destinatario de las mismas deberá comparecer para ser notificado. En todo caso, la comparecencia deberá producirse en el plazo de 15 días naturales, contados desde el siguiente al de la publicación del anuncio en el «Boletín Oficial del Estado». Transcurrido dicho plazo sin comparecer, la notificación se entenderá producida a todos los efectos legales el día siguiente al del vencimiento del plazo señalado.

${ }^{61}$ Salvo que se comparezca dentro de los quince días ulteriores a la publicación edictal, en cuyo caso se entenderá notificada desde ese momento, salvo que rehúse, en cuyo caso se tendrá por practicada (art. 115 RGGI).

${ }^{62}$ STSJ Comunidad Valenciana 14.04.2000.

${ }^{63}$ Entendemos que resulta inconstitucional, y atentatorio al derecho de defensa, lo dispuesto en el art. 112.3 LGT cuando norma que «Cuando el inicio de un procedimiento o cualquiera de sus trámites se entiendan notificados por no haber comparecido el obligado tributario o su representante, se le tendrá por notificado de las sucesivas actuaciones y diligencias de dicho procedimiento, y se mantendrá el derecho que le asiste a comparecer en cualquier momento del mismo. No obstante, las liquidaciones que se dicten en el procedimiento y los acuerdos de enajenación de los bienes embargados deberán ser notificados con arreglo a lo establecido en esta Sección.» 
desplegar una mínima actividad y diligencia en la búsqueda y logro de las notificaciones personales antes de utilizar la vía edictal. No se trata de exigir a la Administración correspondiente el despliegue de una desmedida labor investigadora (STC 55/2003), sino de que adopte, más allá del cumplimiento rituario de las formalidades legales, todas las cautelas y garantías que resulten razonablemente adecuadas para asegurar la notificación personal de los interesados (SsTC 158/2001, 216/2002, 220/2002, 55/2003). Ni siquiera el incumplimiento, por parte del interesado, de su obligación de hacer saber a la Administración los cambios de domicilio puede servir de coartada para que ésta acuda a la notificación edictal sin realizar previamente gestiones para localizar el actual domicilio del interesado (STSJ Andalucía-Sevilla- 14.12.1999, FJ 2. ${ }^{\circ}$ ). Así las cosas, cuando se ignore ${ }^{64}$ el lugar de notificación o el interesado se ausente 'sin dejar señas', debe la Administración tratar de buscar el lugar donde notificar, sobretodo cuando se pueda lograr sin esfuerzos desproporcionados (STS 26.1.2004). Entendemos que, si bien el artículo 111.1 LGT autoriza a diversas personas a recepcionar la notificación, lo que significa -a nuestro modo de ver- que cuando no se haya comunicado al obligado tributario o a su representante [aunque lo haya sido a cualquier persona que se encuentre en dicho lugar o domicilio o a los empleados de la comunidad de vecinos o de propietarios] deberá notificarse también mediante la comunicación edictal, que debe realizarse cuando no sea posible efectuar la notificación al interesado o a su representante por causas no imputables a la Administración tributaria y se haya intentado notificar a estos, al menos, dos veces en el domicilio fiscal, o en el designado por el interesado -entendemos, obligado tributario o su representante- (art. 112.1 LGT) y deberá dejarse al destinatario [obligado tributario o su representante] aviso de llegada en el correspondiente casillero domiciliario, indicándole en la diligencia que se extienda por duplicado, la posibilidad de personación ante la dependencia al objeto de hacerle entrega del acto, plazo y circunstancias relativas al segundo intento de entrega (art.114.1.2 RGGI). El edicto deberá contener lo dispuesto en el art. 112.2 LGT, constando «la relación de notificaciones pendientes con indicación del obligado tributario o su representante, el procedimiento que las motiva, el órgano competente de su tramitación y el lugar y plazo en que el destinatario de las mismas deberá comparecer para ser notificado», y que de no

${ }^{64}$ Para estimar que el domicilio del interesado resulta desconocido para la Administración, ésta habrá de probar que ha desplegado una razonable actividad en pro de la averiguación del mismo, sólo entonces estará habilitada para acudir a la notificación edictal (STSJ Andalucía-Sevilla- 11.6.1999). 
reunir dichos requisitos la notificación debe estimarse incorrecta y carente de efectos ${ }^{65}$.

Tampoco resulta adecuado acudir a la notificación edictal en caso de que se haya realizado el intento de notificación en dos ocasiones en horas distintas en un intervalo de tres días -conforme a la jurisprudencia de la STS de 28.10.2004, respecto del art. 42.2 LPACAP-, sino que exige además que se deje aviso al destinatario y que éste no se haya personado a recogerlo en el plazo para ello [un mes] (art. 42 RSP) ${ }^{66}$, aunque el art. 114.1. II RGGI establece, con menor seguridad jurídica, «una vez realizados los dos intentos de notificación sin éxito en los términos establecidos en el artículo 112.1 de la Ley 58/2003, de 17 de diciembre, General Tributaria, se procederá cuando ello sea posible a dejar al destinatario aviso de llegada en el correspondiente casillero domiciliario, indicándole en la diligencia que se extienda por duplicado, la posibilidad de personación ante la dependencia al objeto de hacerle entrega del acto, plazo y circunstancias relativas al segundo intento de entrega. Dicho aviso de llegada se dejará a efectos exclusivamente informativos.»

En caso de que la notificación se entienda con el representante, la representación deberá resultar válidamente acreditada ${ }^{67}$. Si bien existe un derecho a que la actuación administrativo sancionadora tributaria sea redactada en lengua castellana o cooficial, en caso de que se recepcionase en lengua diferente a la solicitada ello no impediría que operase como notificación conforme, de modo que interrumpiría la prescripción de la acción para sancionar, no pudiéndose aprovechar para desplazar la consideración de la actuación administrativa con conocimiento del administrado ${ }^{68}$.

\section{II.C) Conducente a la imposición de la sanción tributaria}

Materialmente esa actuación debe ser conducente al fin del procedimiento sancionador en cuestión y no del de otra infracción tributaria, y ello porque, como advirtiera Mantero $(1978)^{69}$, la idea fundamental de todo procedimiento es la progresión, desarrollo y avance de tal modo que cada acto, dentro del procedimiento en cuestión, debe

${ }^{65}$ STSJ Murcia 14.12.2001; aunque la notificación edictal defectuosa surte los efectos cuando el interesado interpone el recurso procedente, STSJ Murcia 27.4.2000.

${ }^{66}$ STS 12.12.1997; STSJ Extremadura 15.07.2003.

${ }^{67}$ AA. VV (Dir. Martínez Lafuente, A.): Estudios ... op. cit. pág. 399.

${ }^{68}$ STSJ Illes Balears de 9.03.1997.

${ }^{69}$ Citado por Juan Lozano, A. M.: La interrupción... op. cit, pág. 35. 
reunir tres notas: progresiva, teleológica y ritual, de tal forma que cada acto aislado no sólo debe tender al fin, sino que debe adelantar respecto del anterior, y todo ello debe llevarse a cabo observando unas formalidades. Si no se cumplen esos principios generales, se estaría produciendo una confusión de la causa con el efecto, y ante ello desaparecería la virtualidad interruptiva de la actuación en cuestión. Naturalmente, la respuesta a cuándo una de las actuaciones previstas en el art. 189.3.a) LGT reviste plena eficacia a estos efectos no es posible formularla a nivel de principio, sino que tendrá que ser un examen de las circunstancias particulares del caso el que determine si se cumplen o no lo condicionantes que hacen quebrar la paralización de las potestades de la Administración Tributaria.

El conocimiento efectivo de la resolución, como momento interruptivo de la prescripción, no puede tomarse como un dogma infranqueable. Cuando la notificación se ha 'intentado' en forma legal, tal intento de notificación será hábil para interrumpir la prescripción, en cuanto acto con proyección externa ${ }^{70}$. Se trata de afrontar, en definitiva, las actuaciones fraudulentas o negligentes del interesado, ocultando su verdadera dirección o cambiando de domicilio sin comunicarlo a la Administración, y evitar que puedan servir de coartada para eludir la notificación personal de la sanción, dilatar el procedimiento y lograr así la prescripción. Por ello, la notificación no tiene que ser necesariamente recepcionada, por su destinatario, representante o quien se encuentre en su domicilio, para que interrumpa la prescripción, basta que haya sido cursada a tal domicilio para que una vez intentada con arreglo a los requisitos legales, aunque fracase, ello sea suficiente al objeto de interrumpir la prescripción ${ }^{71}$, lo cual no excusa a la Administración de intentar la segunda notificación domiciliaria (art. 42.2 LPACAP) y de realizar cuantas diligencias estén razonablemente a su alcance para, en su caso, localizar otro domicilio, o lugar donde efectuar la notificación personal, antes de proceder a la residual y ficticia notificación edictal ${ }^{72}$. Dado que las notificaciones hechas en legal forma son eficaces para interrumpir la prescripción por

${ }^{70} \mathrm{Ha}$ de pensarse en aquellos casos en que la omisión o frustración de los actos de comunicación tienen su causa en la falta de diligencia del afectado en la defensa de sus derechos e intereses, bien porque se ha colocado al margen del procedimiento mediante una actitud pasiva con el fin de obtener una ventaja de esa marginación, bien cuando resulte probado que poseía conocimiento extraprocesal de la existencia del litigio en el que no fue personalmente emplazado (STC 55/2003).

${ }^{71}$ Así la generalidad de los Tribunales Superiores de Justicia. STSJ Aragón 29.9.1999, STSJ Castilla Y León -Burgos- 16.1.1999, STSJ Comunidad Valenciana 29.10.1997.

72 De Diego Díez, L. A.: ... op. cit. pág. 96 
el motivo que ahora analizamos, habrá que estarse, a tal fin, a lo dispuesto en las especialidades de los artículos 109 a 112 LGT $^{73}$, y a los arts. 41 a 46 LPACAP (en lo que no contradigan a aquéllas especialidades) y para las notificaciones por correo a lo previsto en los arts. 39 a 44 del Reglamento de los Servicios Postales (RD 1829/1999, de 3 de diciembre-RSP-) y a lo previsto en los artículos 14,16, 17,22.4, 23, 24 y 25 de la ley 43/2010, de 30 de diciembre, del servicio postal universal, de los derechos de los usuarios y del mercado postal (LSPU).

Desde nuestro punto de vista, la ley no reserva esta causa de interrupción para un tipo determinado de actuaciones, ahora bien, pensamos que la aplicación del principio de independencia de procedimientos, que demanda que los actos interruptivos de un procedimiento estén dirigidos a la consecución de su resolución ${ }^{74}$,

${ }^{73}$ Por remisión del art.209 LGT a los arts. 109 a 112 LGT, y del art. 109 LGT a las normas administrativas generales-, como también por la que efectúan los arts. 178.1. ${ }^{\circ}$, 207.b) y 208.4 LGT, sin perjuicio que para la notificación de la resolución del procedimiento sancionador se remita el art. 211.2 LGT al art. 104.2 LGT, a los solos efectos de entender notificado en el plazo especial de caducidad de seis meses que impone el art. 211.2 LGT; En materia de notificaciones el artículo 208.4 LGT remite a las normas generales, previstas en los artículos 109 a 112, de la aplicación de los tributos; y, su vulneración, supone la nulidad del acto administrativo al implicar la violación del derecho fundamental de defensa [artículo 62.1.a) de la Ley 30/1992] (hoy art. 47.1.a $\angle P A C A P$ ) integrante del derecho a la tutela judicial efectiva del artículo $24 \mathrm{CE}$, y habilitará el posible ejercicio de las acciones que nuestro derecho contempla en garantía de los derechos fundamentales. Como señala la STC de 18 de junio de 1981 el artículo 24 CE no es solamente de aplicación a los procesos judiciales sino también a los procedimientos administrativos de índole sancionadora. En todo lo no previsto en los artículos 109 a 112 LGT será de aplicación las disposiciones previstas para los procedimientos administrativos y, en consecuencia, como dice la DGT en Consulta V103905, de fecha 10 de junio de 2005, al no existir previsión alguna será de aplicación lo dispuesto en el artículo 58 de la Ley 30/1992 (hoy art. 40.2 LPACAP): «Toda notificación deberá ser cursada dentro del plazo de diez días a partir de la fecha en que el acto haya sido dictado...». Morato Miguel, L. C.: «El régimen sancionador tributario», en la obra colectiva El Sistema Fiscal Español y las Entidades y Operaciones Financieras, La Ley, edición núm. 1, Madrid, abril 2006.

${ }^{74}$ Un tema controvertido en la jurisprudencia ha sido el de la eficacia interruptiva de las liquidaciones, definitivas o provisionales, de las que no deriva deuda alguna. El tema se ha planteado sobre todo en relación con el «derecho» a liquidar, pero su solución puede extenderse, en los mismos términos, a la interrupción de la prescripción de las infracciones. En su sentencia de 17 de enero de 1975 el Tribunal Supremo afirmaba que «no puede calificarse de actuación administrativa eficaz para interrumpirla prescripción la práctica de unas liquidaciones provisionales que lo único que acreditan es que la sociedad contribuyen te hizo unos ingresos a cuenta excesivos, pero que no mantenían abierta la posibilidad de exigir diferencias en favor de la Administración». A nuestro juicio, esta doctrina es equivocada, pues en el tenor literal del art. 55.1.a) caben tanto las liquidaciones que arrojen una mayor cuota como aquellas de las que resulte una cantidad a devolver. En ambos casos se trata de actos de la Administración tendentes a determinar su derecho, y por tanto interrumpen la prescripción tanto de la obligación tributaria, como de la responsabilidad derivada 
requiere que el plazo de prescripción derivado de la comisión de una infracción, inicialmente, sólo se interrumpa, cualquiera que sea la gravedad de la misma y los órganos que la establezcan, cuando se inicia el procedimiento sancionador y, una vez iniciado el procedimiento, dado que en este ámbito la prescripción tiene efectos instantáneos, cuando se produzca una actuación de la Administración Tributaria tendente a hacer avanzar el procedimiento sancionador y obtener la resolución del mismo ${ }^{75}$.

\section{CONCLUSIONES}

Desde nuestro punto de vista, la presente causa de interrupción, sería la única causa natural y deseable que debiera interrumpir el procedimiento dirigido a la determinación de la responsabilidad infractora tributaria, desechando las conducentes a la regularización de la situación tributaria, por encontrarse legalmente separados los procedimientos de aplicación de los tributos y los procedimientos sancionadores tributarios.

de eventuales infracciones. Falcón y Tella, R.: Análisis Crítico... op. cit. pág. 85. Dicha sentencia fue comentada y criticada por Escribano López, F. y Pérez Royo, F. en el núm. 19 de Crónica Tributaria, 1976. La eficacia interruptiva de las liquidaciones provisionales es, en cambio, aceptada por el TEAC (Resolución de 18 de septiembre de 1973, citada por MANTERo SÁENZ, A.: "La prescripción en Derecho Tributario», CaT, monografías, núm. 14, 1985, pág. 168.

${ }^{75} \mathrm{La}$ acción de la Administración ha de ser conducente a la imposición de la sanción. Nos parece incorrecta la expresión, primero porque aún en el caso de prescripción manifiesta será necesario iniciar el procedimiento y conducirlo a la declaración de la infracción, para luego conducirlo a la aplicación de la prescripción y, por último, no conducirlo a la imposición de la sanción. Cierto es que cuando se aplique la prescripción de oficio, el inicio del procedimiento no habrá interrumpido nada porque nada existía, pero eso lo sabemos después. En el momento del inicio el plazo de prescripción ha de quedar interrumpido, sin perjuicio de que más tarde se compruebe que la prescripción ya había sido ganada y el plazo no se podía interrumpir simplemente porque no estaba vivo. En segundo lugar, porque puede inducir a dudas el que se requiera que la acción haya de ser conducente a la imposición de la sanción, al interpretar que esa conducción significa una relación directa e inmediata, cosa muy discutible como hemos visto cuando se inicia un procedimiento sancionador. Por último, porque no se define qué se ha de entender por acción conducente, lo que puede generar problemas de litigiosidad. LAmoca PéREZ, C.: Infracciones... op . cit. pág. 221; También las actuaciones, no sólo de incoación, sino de instrucción del procedimiento sancionador tienen eficacia interruptiva. Las actuaciones administrativas debidamente notificadas deben surtir los efectos que le son propios como ejercicio de la potestad sancionadora, esto es, la persecución de la infracción....la prescripción sólo debe producirse en el caso de que no se actúe. Sólo en la caducidad encontramos el efecto extintivo pese a la actividad de la Administración, si es rebasado el plazo para resolver. (1) DE Miguel CANuTO, E.: La prescripción... op. cit. págs. 27 a 32. 
Conforme a todo lo expuesto en este artículo, para interrumpir la prescripción del procedimiento conducente a la determinación de la responsabilidad infractora de naturaleza tributaria resultará necesario:

a) Que exista una actuación administrativa, pero no cualquier actuación, sino una actuación de naturaleza sancionadora y que legal o reglamentariamente forme parte del procedimiento sancionador tributario y haga avanzar y progresar respecto de la concreta sanción tributaria, y no respecto de cualquier otro incumplimiento que pudiera haberse producido.

b) Que dicha la actuación administrativa provenga de la Administración Tributaria legalmente competente.

c) Que dicha actuación administrativa emane de un órgano con competencias sancionadoras normativamente atribuidas en la correspondiente Administración tributaria.

d) Dicha actuación administrativa debe de ser formal y correctamente notificada al presunto infractor o a su legal representante. El escrupuloso cumplimiento ritual de las normas tributarias, administrativas y postales que regulan la notificación (así persona que deba de hacerse cargo de la notificación, lugar de notificación, notificación edictal, intentos de notificación, cumplimentación de los acuses de recibo, depósito de avisos de notificación, rehúse de notificaciones e incluso el ritualismo para las notificaciones telemáticas voluntariamente aceptadas u obligatorias por razón del sujeto obligado), hará que se perfeccione o no la actuación sancionadora dictada, interruptiva de la prescripción de la correspondiente infracción tributaria. 